\title{
EFFECT OF COMPOST, NITROGEN AND MICRONUTRIENT COMPOUNDS ON NITROGEN UPTAKE, YIELD AND YIELD COMPONENTS OF WHEAT \\ El-Hamdi, Kh. H. ${ }^{*}$; A. R. Ahmed ${ }^{* \star}$ and N. E. S. El-Azzony ${ }^{* *}$ \\ 'Soils Dept., Fac. of Agriculture, Mansoura Univ., Egypt. \\ Soils water and Environ. Res. Inst., Agric. Res. Center, Egypt. \\ ABSTRACT
}

The objective of this study is to investigate the influence of compost, nitrogen and micronutrient compounds fertilization on $\mathrm{N}$-uptake, yield and yield components of wheat. A field experiment was carried out at Met-Dafer; Dekernes, Dakahliagovernerate, Egypt during the two successive winter seasons of 2008/2009 and 2009/2010. The experiment was conducted in a split split plot design; which consisted of three compost treatments $\left(0,5\right.$ and 10 ton $\left.^{-1} \mathrm{de}^{-1}\right)$ as main plots, nitrogen fertilization levels $\left(0,50\right.$ and $\left.75 \mathrm{~kg} \mathrm{~N} \mathrm{fed}^{-1}\right)$ as sub plots and four treatments of micronutrient compounds (control, sitrin , sitrin + kotingin and kotingin) as sub sub plots. The obtained results indicated that compost and micronutrient compounds fertilization with nitrogen fertilization increased $\mathrm{N}$-uptake, yield and yield components of wheat and 10 ton $\mathrm{fed}^{-1}$ compost treatment was the superior and the micronutrient compounds treatments excelled control and the sitrin + kotingin treatment was top treatment. The combination of compost and micronutrients along with nitrogen application improved yield, yield components and $\mathrm{N}$-uptake. The best treatment was sitrin + kotingin at 50 $\mathrm{kg} \mathrm{N}$ fed $^{-1}$ with adding compost 10 ton fed ${ }^{-1}$

Keywords: Wheat, micronutrient compounds, compost, nitrogen fertilization Nuptake.

\section{INTRODUCTION}

Wheat (Triticm aestivum, L.) is considered one of the most important cereal crops in Egypt. The amount needed from it is greater than that locally produced. Therefore, increasing its productivity as well as cultivated area is highly recommended.

Nitrogen plays a vital role in increasing the yield of crop. Application of proper amount of nitrogen is considered key to obtain bumper crop of wheat. Nitrogen fertilizer is important for improving grain yields of wheat crop. However, excessive amounts and appropriate application methods lead to low $\mathrm{N}$ efficiency and high fertilizer losses through leaching, denitrification, and volatilization (Kirda, et al., 2001), resulting in a series of environmental problems. Low $\mathrm{N}$ efficiency also increases production costs, leading to lower net returns for farmers (Wang et al., 2001). Thus, efficient $\mathrm{N}$ utilization should be realized in agriculture for environmental and economic reasons (Stevens et al., 2005; Delin et al., 2008).

Compost has a high nutritional value, with high concentrations of especially nitrogen, phosphorus and potassium, while the contamination by heavy metals and other toxic substances are very low. (Asghar et al., 2006). In order to improve the nitrogen application management. Previous studies showed that the combination of compost with chemical fertilizer further enhanced the biomass and grain yield of crops (Cheuk et al. 2003; Sarwar et al. 2007; Sarwar et al., 2008). 


\section{El-Hamdi, Kh. H. et al.}

The micronutrients play an important role in increasing crop yield and have prominent effects on dry matter, grain yield and straw yield of wheat Malakouti and Tehrani, (2005).

This research aims to investigate the effect of different micronutrient compounds in the presence of compost addition for minimizing the rate of nitrogen fertilization; improving the $\mathrm{N}$-uptake, yield and its components and quality parameters of wheat plant. under alluvial soil conditions.

\section{MATERIALS AND METHODS}

A micro field experiment was carried out at Met-Dafer, Dekernes; Dakahlia-governerate, Egypt during the two successive winter seasons of 2008/2009 and 2009/2010 on an alluvial soil. The experiment was conducted in a split split plot design; which consisted of three compost treatments $(0$ and 5 ton fed ${ }^{-1}$ in the $1^{\text {st }}$ season and 0,5 and 10 ton fed ${ }^{-1}$ in $2^{\text {nd }}$ season in main plots, three levels of nitrogen fertilization $\left(0,50\right.$ and $\left.75 \mathrm{~kg} \mathrm{~N}^{\mathrm{fed}}{ }^{-1}\right)$ in sub plot and four treatments of micronutrient compounds (control, sitrin , sitrin + kotingin and kotingin) in sub sub plot. Each treatment was replicated 3 times and the total number of studied plots was 72 plots in the $1^{\text {st }}$ season and 108 plots in the $2^{\text {nd }}$ season. The interaction effects between these treatments were also studied. The plot area was $2.25 \mathrm{~m}^{2}(1.5 \times 1.5 \mathrm{~m})$. All other agriculture conservations were done. Addition of compost to each plot (two weeks before sowing wheat seeds). Each plot received 0 and 5 ton compost fed ${ }^{-1}$ in the $1^{\text {st }}$ season i.e. 0 and $2.678 \mathrm{Kg}_{\text {compost }}$ and 0,5 and 10 ton compost fed ${ }^{-1}$ i.e. 0 , 2.678 and $5.35 \mathrm{Kg}$ compost .

On $11^{\text {th }}$ November, 2008 and 2009 in both season, wheat seeds CV Sakha 93 were sown in each plot at rate of $60 \mathrm{Kg} \mathrm{fed}^{-1}$. For the treatment of kotingin; wheat seeds were coated with this material at sowing process, while sitrin was foliarly applied twice of 30 and 60 days from sowing .treated with Kotingen, Nitrogen fertilizer in the form of ammonium sulphate was added at the rates of 0,50 and $75 \mathrm{~kg} \mathrm{~N}^{-1}(0,242,364$ and $485 \mathrm{~g}$ per plot) in two doses ; 60 and $40 \%$, respectively. The $1^{\text {st }}$ dose was applied after 30 days and the other 30 days later. Potassium sulfate $48 \%$ and calcium-super phosphate $15.5 \% \mathrm{P}_{2} \mathrm{O}_{5}$ were the respective source of $\mathrm{K}$ and $\mathrm{P}$, which added as a soil application before sowing. The plants were harvested in May 2009 and 2010.

The studied soil was loamy in texture. Some physical and chemical properties of the studied soil before cultivation are presented in Table 1, and also compost analysis in Table 2.

Particle size distribution was determined using the international pipette method as described by Piper, (1950). Soil pH was measured in 1: 2.5 soil water suspensions as described by Jackson, (1967). Saturation percentage was determined as described by the US Salinity Laboratory Staff (1954). Electrical conductivity (EC) was measured in the 1:5 soil water extract using the electrical conductivity meter (Jackson, (1967). Organic matter was determined according to Walkley and Black method (Black, (1965). Calcium carbonate was measured volumetrically using collin's calcimeter according to 
Piper (1950). Soluble captions and anions were measured in 1:5 soil water extract according to the methods described by Jackson, (1967).

Available phosphorus in the studied soil was extracted by sodium bicarbonate and determined following the method of Olsen et al., (1954). Available potassium was extracted by ammonium acetate and measured by flame photometerically according to Black, (1965). Total nitrogen was determined by using microkejeldahl method as described by Pregle, (1945). Total phosphorus was determined colormetrically using cholrostannus-reduce molybdo-phosphoric blue color method in sulphuric acid as described by Jackson, (1967). Potassium was determined in the digested plant materials using the flame photometer as described by Black, (1965).

Table 1: Some physical and chemical properties of soil studied.

\begin{tabular}{|c|c|c|c|c|c|c|c|c|c|}
\hline \multirow{4}{*}{$\begin{array}{c}\text { physical } \\
\text { analysis }\end{array}$} & \multicolumn{5}{|c|}{ Particle size distribution } & SP\% & $\begin{array}{c}\text { OM } \\
\%\end{array}$ & $\mathrm{CaCO}_{3} \%$ \\
\cline { 2 - 10 } & Coarse sand \% & Fine sand \% & $\begin{array}{c}\text { Silt } \\
\%\end{array}$ & $\begin{array}{c}\text { Clay } \\
\%\end{array}$ & $\begin{array}{c}\text { Texture } \\
\text { class }\end{array}$ & & & &
\end{tabular}

Table2: Some chemical properties of compost used.

\begin{tabular}{|c|c|c|c|c|c|c|c|c|c|c|c|}
\hline parameters & $\begin{array}{c}\mathbf{E} . \mathbf{C}^{\prime \prime} \\
\mathbf{d S ~}^{-1}\end{array}$ & $\mathbf{p H}^{\star}$ & $\begin{array}{c}\text { Total } \\
\mathbf{N} \%\end{array}$ & $\begin{array}{c}\text { Total } \\
\mathbf{C} \%\end{array}$ & $\mathbf{C}: \mathbf{N}$ & $\begin{array}{c}\text { Total } \\
\mathbf{p} \%\end{array}$ & $\begin{array}{c}\text { Total } \\
\mathbf{k} \%\end{array}$ & $\begin{array}{c}\mathbf{F e} \\
(\mathbf{p p m})\end{array}$ & $\begin{array}{c}\mathbf{M n} \\
(\mathbf{p p m})\end{array}$ & $\begin{array}{c}\mathbf{Z n} \\
(\mathbf{p p m})\end{array}$ & $\begin{array}{c}\mathbf{C u} \\
(\mathbf{p p m})\end{array}$ \\
\hline Value & 5.38 & 8.69 & 1.19 & 22 & $18: 1$ & 0.23 & 0.126 & 241 & 197 & 49 & 28 \\
\hline
\end{tabular}

Available micronutrients in soil samples were extracted by DTPA solution according to Lindsay and Norvall (1978) and determined using the Atomic Absorption Spectrophotometer.

The plant samples were taken from each plot. N-uptake, yield and yield component; grain yield $\left(\operatorname{ard~fed~}^{-1}\right)$, straw yield (ton fed $\left.{ }^{-1}\right)$, spike No $\mathrm{m}^{-2}, 100$ grain weight in $\mathrm{g}$ and protein percent were determined. The plant samples were grinned to fine powder and $0.2 \mathrm{~g}$ was wet digested with a mixture of sulfuric acid $\left(\mathrm{H}_{2} \mathrm{SO}_{4}\right)$ and perchloric acid $\left(\mathrm{HclO}_{4}\right)$ for the different analyses

Protein \% in grain and straw were calculated by multiply $\mathrm{N}$ percentage by 5.83 for wheat according to (Baker, 1979).

Statistical analysis: Statistical analysis of the collected data was done according to the methods described by (Gomez and Gomez 1984). 


\section{RESULTS AND DISCUSSION}

\section{Effect of compost, nitrogen and micronutrient compounds fertilization on $\mathrm{N}$-uptake in grain and straw yields of wheat:}

Data in Table 3 show the mean values of $\mathrm{N}$-uptake in grain and straw yields in $\mathrm{kg} \mathrm{fed}^{-1}$ during the two seasons as affected by compost, nitrogen and micronutrient compounds fertilization during both seasons of the experiment and the results were as follow:-

\section{A. Compost effect:}

As shown in Table 3, the compost application increases the $\mathrm{N}$-uptake in grain and straw yields in both seasons and the high significant increases were obtained, $\mathrm{N}$-uptake value in grain yield increases with increasing application rate of compost fed ${ }^{-1}$ and the highest value was $42.41 \mathrm{~kg} \mathrm{fed}^{-1}$ in $1^{\text {st }}$ season with 5 ton fed ${ }^{-1}$ compost and $54.85 \mathrm{~kg} \mathrm{fed}^{-1}$ in $2^{\text {nd }}$ season with 10 ton fed ${ }^{-1}$ compost compared to control $\left(29.91\right.$ and $31.73 \mathrm{~kg} \mathrm{fed}^{-1)}$ in both seasons, respectively) The $\mathrm{N}$-uptake in straw yield shows significant increase with increasing compost application and the top value was $19.9 \mathrm{~kg} \mathrm{fed}^{-1}$ in $1^{\text {st }}$ season with 5 ton fed ${ }^{-1}$ compost and $27.31 \mathrm{~kg} \mathrm{fed}^{-1}$ in $2^{\text {nd }}$ season with 10 ton fed $^{-1}$ compost compared to control (13.39 and $13.82 \mathrm{~kg} \mathrm{fed}^{-1)}$ in both seasons, respectively. These increases in $\mathrm{N}$-uptake values in grain and straw yield could be due to compost fertilization where it has a high nutritional value, with high concentrations of especially nitrogen and to improving physical and chemical soil properties. The results trend goes with Sarwar et al., (2007) and Sarwar et al., (2008).

\section{B. Nitrogen Effect:}

High significant increases in nitrogen-uptake in grain and straw yield of wheat were showed in Table 3, influnced by nitrogen application. The use of $75 \mathrm{~kg} \mathrm{~N}$ fed ${ }^{-1}$ treatment recorded the highest value which were 47.97 and $56.35 \mathrm{~kg} \mathrm{~N}^{-1} \mathrm{~d}^{-1}$ in both seasons, respectivly followed by $50 \mathrm{~kg} \mathrm{~N}$ fed ${ }^{-1}$ compared to control (25.34 and $24.75 \mathrm{~kg} \mathrm{~N}$ fed $\left.^{-1}\right)$ in both seasons of $\mathrm{N}$-uptake in straw yield, the heighest mean also was with $75 \mathrm{~kg} \mathrm{~N}$ fed $^{-1}$ (20.53 and $31.14 \mathrm{~kg} \mathrm{~N}$ fed $\left.^{-1}\right)$ followed by $50 \mathrm{~kg} \mathrm{~N}$ fed $^{-1}$ compared to control (10.64 and $11.12 \mathrm{~kg} \mathrm{~N} \mathrm{fed}^{-1}$ ). This trend agree with El-Zeky, (2005).

\section{Micronutrient compounds effect:}

Data in Table 3 show high significant increases in $\mathrm{N}$-uptake mean values in grain and straw yields as affected by micronutrient compounds application and studied micronutrient compound treatments excelled control. These results indicate that the role of micronutrients addition in improving grain yield $\mathrm{N}$-uptake of wheat. The $\mathrm{N}$-uptake values increases with studied micronutrient compounds more than control and the highest mean value was with sitrin + kotingin treatment $\left(42.28 \mathrm{~kg} \mathrm{~N}^{-1} \mathrm{fe}^{-1}\right)$ followed by solo kotingin $(37.57 \mathrm{~kg} \mathrm{~N}$ $\left.\mathrm{fed}^{-1}\right)$ then sitrin $\left(34.01 \mathrm{~kg} \mathrm{~N} \mathrm{fed}^{-1}\right)$ compared to control $\left(30.76 \mathrm{~kg} \mathrm{fed}^{-1}\right)$ in $1^{\text {st }}$ season, as well in $2^{\text {nd }}$ season. This trend is identical with $\mathrm{N}$-uptake values in straw yield, the highest mean was with sitrin + kotingin treatment $(17.22 \mathrm{~kg} \mathrm{~N}$ $\left.\mathrm{fed}^{-1}\right)$ followed by solo sitrin $\left(16.06 \mathrm{~kg} \mathrm{~N} \mathrm{fed}^{-1}\right)$ then kotingin $\left(16.06 \mathrm{~kg} \mathrm{~N} \mathrm{fed}^{-1}\right)$ compared to control $\left(13.23 \mathrm{~kg} \mathrm{fed}^{-1}\right)$ in $1^{\text {st }}$ season, also in $2^{\text {nd }}$ season except 
the kotingin excelled sitrin, but all treatments excelled control. Similar results were reported by Malakouti and Tehrani, (2005).

Table 3: Means of nitrogen-uptake in grain and straw of wheat as affected by compost, nitrogen and micronutrient compounds during both seasons.

\begin{tabular}{|c|c|c|c|c|c|}
\hline \multirow{3}{*}{\multicolumn{2}{|c|}{ Treatment }} & \multicolumn{4}{|c|}{ N-uptake } \\
\hline & & \multicolumn{2}{|c|}{ Grain (kg fed $\left.{ }^{-1}\right)$} & \multicolumn{2}{|c|}{ Straw $\left(\mathrm{kg} \mathrm{fed}^{-1}\right)$} \\
\hline & & $1^{\text {st }}$ season & $2^{\text {nd }}$ season & $1^{\text {st }}$ season & $2^{\text {nd }}$ season \\
\hline \multirow{3}{*}{ A- Compost } & control & 29.91 & 31.73 & 13.39 & 13.82 \\
\hline & 5 tons & 42.41 & 38.76 & 16.90 & 23.99 \\
\hline & 10 tons & -- & 54.85 & -- & 27.31 \\
\hline \multicolumn{2}{|c|}{ LSD } & 0.36 & 1.44 & 0.29 & 1.31 \\
\hline \multirow{3}{*}{ B-Nitrogen } & control & 25.34 & 24.75 & 10.64 & 11.12 \\
\hline & $50 \mathrm{~kg}$ & 35.16 & 44.24 & 14.26 & 22.86 \\
\hline & $75 \mathrm{~kg}$ & 47.97 & 56.35 & 20.53 & 31.14 \\
\hline \multicolumn{2}{|c|}{ LSD } & 0.72 & 2.09 & 0.13 & 0.84 \\
\hline \multirow{4}{*}{ C-Micronutrient } & Control & 30.76 & 33.07 & 13.23 & 15.55 \\
\hline & Sitrin & 34.01 & 38.85 & 16.06 & 19.29 \\
\hline & Sit.+Kot. & 42.28 & 50.13 & 17.22 & 28.56 \\
\hline & Kotingin & 37.57 & 45.06 & 14.07 & 23.42 \\
\hline \multicolumn{2}{|c|}{ LSD } & 0.62 & 2.19 & 0.20 & 0.76 \\
\hline
\end{tabular}

D. Interaction effect among compost, nitrogen and micronutrient compounds on yield $\mathrm{N}$-uptake of wheat.

As shown in Tables 4 and 5 , the $\mathrm{N}$-uptake values in grain and straw yield increased with compost, nitrogen and micronutrient compounds fertilization interaction. These increases were from zero up to 10 ton fed $^{-1}$ compost and from zero up to $75 \mathrm{~kg} \mathrm{~N} \mathrm{fed}^{-1}$ for nitrogen fertilization.

The highest value was $67.04 \mathrm{~kg} \mathrm{~N}^{-1} \mathrm{fed}^{-1}$ with sitrin + kotingin at $75 \mathrm{~kg}$ $\mathrm{N}$ fed ${ }^{-1}$ with 5 ton compost fed ${ }^{-1}$ followed by solo Kotngen treatment $(60.38 \mathrm{~kg}$ $\mathrm{fed}^{-1}$ ) then sitrin (50.95) compared to control (4.91) in $1^{\text {st }}$ season and in $2^{\text {nd }}$ season the highest was $83.11 \mathrm{~kg} \mathrm{fed}^{-1}$ with sitrin + kotingin at $50 \mathrm{~kg} \mathrm{~N}$ fed with10 ton compost fed ${ }^{-1}$ followed by sitrin + kotingin with $75 \mathrm{~kg} \mathrm{~N}$ at 10 ton compost fed ${ }^{-1}$ then Kotingin with $\mathrm{kg} \mathrm{N}^{-1} \mathrm{f}^{-1}$ compared to control(5.07). Also in straw, the highest value in $1^{\text {st }}$ season was with $75 \mathrm{~kg} \mathrm{~N}$ fed $\left(24.17 \mathrm{~kg} \mathrm{~N}\right.$ fed $\left.^{-1}\right)$ at 5 ton compost but in $2^{\text {nd }}$ season the highest was $48.96 \mathrm{~kg} \mathrm{~N}^{-1} \mathrm{ded}^{-1}$ at $50 \mathrm{~kg}$ fed ${ }^{-1}$ at 10 ton fed followed by $42.33 \mathrm{~kg} \mathrm{~N}$ fed ${ }^{-1}$ at $75 \mathrm{~kg} \mathrm{~N}^{-1}{ }^{-1}$ with 10 ton compost. Studied treatments excelled control $\left(4.14 \mathrm{~kg} \mathrm{~N} \mathrm{fed}^{-1}\right)$. These results demonstrate that the combination between micronutrients and compost maximize $\mathrm{N}$-use efficiency and improves $\mathrm{N}$-uptake, yield and yield components. These results go with those reported by Malakouti, (2000); Malakouti and Tehrani, (2005); Malakouti, (2007) and Rehm and Albert, (2006). 
Table 4: Effect of the interaction between compost, nitrogen and micronutrient compounds on $\mathrm{N}$-uptake $\left(\mathrm{kg} \mathrm{fed}^{-1}\right)$ in grain and straw yields of wheat during the first season.

\begin{tabular}{|c|c|c|c|c|}
\hline \multicolumn{3}{|c|}{ Treatment } & \multirow{2}{*}{\multicolumn{2}{|c|}{ Nitrogen-uptake $\mathbf{k g ~ f e d}^{-1}$}} \\
\hline \multirow{2}{*}{$\begin{array}{l}\text { Compost, } \\
\text { ton fed. }{ }^{-1}\end{array}$} & \multirow{2}{*}{$\begin{array}{|cc|}\begin{array}{c}\text { Nitrogen, } \\
\text { fed }^{-1}\end{array} & \mathbf{k g} \\
\end{array}$} & \multirow{2}{*}{$\begin{array}{c}\text { Micronutrient } \\
\text { Compounds }\end{array}$} & & \\
\hline & & & Grain & Straw \\
\hline \multirow{12}{*}{$\begin{array}{l}\text { Without } \\
\text { Compost }\end{array}$} & \multirow{4}{*}{$0 \mathbf{~ k g}$} & Control & 14.91 & 6.52 \\
\hline & & Sitrin & 18.55 & 9.55 \\
\hline & & Sitr.+Kotin. & 23.21 & 10.67 \\
\hline & & Kotingen & 19.11 & 7.70 \\
\hline & \multirow{4}{*}{$50 \mathrm{~kg}$} & Control & 26.56 & 11.37 \\
\hline & & Sitrin & 28.75 & 13.88 \\
\hline & & Sitr.+Kotin. & 36.74 & 11.65 \\
\hline & & Kotingen & 31.44 & 10.02 \\
\hline & \multirow{4}{*}{$75 \mathrm{~kg}$} & Control & 33.84 & 16.86 \\
\hline & & Sitrin & 38.39 & 19.22 \\
\hline & & Sitr.+Kotin. & 47.94 & 23.20 \\
\hline & & Kotingen & 39.46 & 20.00 \\
\hline \multirow{12}{*}{5 ton Compost } & \multirow{4}{*}{$0 \mathbf{~ k g}$} & Control & 28.55 & 11.20 \\
\hline & & Sitrin & 29.82 & 13.54 \\
\hline & & Sitr.+Kotin. & 36.28 & 14.57 \\
\hline & & Kotingen & 32.29 & 11.36 \\
\hline & \multirow{4}{*}{$50 \mathrm{~kg}$} & Control & 34.96 & 14.46 \\
\hline & & Sitrin & 37.62 & 17.66 \\
\hline & & Sitr.+Kotin. & 42.47 & 19.04 \\
\hline & & Kotingen & 42.76 & 16.04 \\
\hline & \multirow{4}{*}{75 kg } & Control & 45.76 & 18.96 \\
\hline & & Sitrin & 50.95 & 22.53 \\
\hline & & Sitr.+Kotin. & 67.04 & 24.17 \\
\hline & & Kotingen & 60.38 & 19.32 \\
\hline \multicolumn{3}{|c|}{ LSD at 0.05} & 1.21 & 0.57 \\
\hline
\end{tabular}

Effect of compost on wheat yield and yield components:

Data in Tables 6 and 7 show the mean values of grain yield in ard fed $^{-1}$ and straw yield in ton fed ${ }^{-1}, 100$ grain weight in g, spike No $\mathrm{m}^{2}$ and crude protein percent in grain and straw as influenced by compost, nitrogen and micronutrient compounds fertilization and the results are as follows:-

\section{A. Compost effect:}

As shown in Tables 6 and 7, the compost addition increases grain and straw yield and significant increases were obtained, the grain yield mean values increases from zero to 5 to 10 ton compost fed $^{-1}$ and the highest values were $13.29 \mathrm{ard} \mathrm{fed}^{-1}$ at 5 ton compost in $1^{\text {st }}$ season and $15.49 \mathrm{ard} \mathrm{fed}^{-1}$ with 10 ton fed ${ }^{-1}$ compost compared to control $\left(9.84\right.$ and 10.65 ard fed $\left.^{-1}\right)$ in both seasons, respectively. Also, the straw yield shows significant increase with compost addition and the top values were 2.88 in $1^{\text {st }}$ season at 5 ton fed ${ }^{1}$ compost compared to 2.38 ton fed ${ }^{-1}$ for control and 3.62 ton fed $^{-1}$ with 10 ton compost fed ${ }^{-1}$ in $2^{\text {nd }}$ season followed by 3.37 ton fed $^{-1}$ at 5 ton compost fed and the less mean value was 2.79 ton fed $^{-1}$ with control. These increases in grain and straw yields could be due to compost fertilization effect where it has 
a high nutritional value, with high concentrations of nutrients especially, nitrogen.

Table 5: Effect of the interaction between compost, nitrogen and micronutrient compounds on $\mathrm{N}$-uptake in Grain and Straw yield $\left(\mathrm{kg} \mathrm{feddan}^{-1}\right)$ of wheat during the second season.

\begin{tabular}{|c|c|c|c|c|}
\hline \multicolumn{3}{|c|}{ Treatment } & \multirow{2}{*}{\multicolumn{2}{|c|}{ Nitrogen-uptake, $\mathrm{kg} \mathrm{fed}^{-1}$}} \\
\hline \multirow{2}{*}{$\begin{array}{l}\text { Compost, } \\
\text { ton fed. }^{-1}\end{array}$} & \multirow{2}{*}{$\begin{array}{l}\text { Nitrogen, } \\
\text { kg fed }^{-1}\end{array}$} & \multirow{2}{*}{$\begin{array}{c}\text { Micronutrient } \\
\text { Compounds }\end{array}$} & & \\
\hline & & & Grain & Straw \\
\hline \multirow{12}{*}{$\begin{array}{l}\text { Without } \\
\text { Compost }\end{array}$} & \multirow{4}{*}{ Zero } & Control & 15.07 & 4.14 \\
\hline & & Sitrin & 16.52 & 6.07 \\
\hline & & Sitr.+Kotin. & 18.61 & 7.06 \\
\hline & & Kotingen & 16.98 & 6.50 \\
\hline & \multirow{4}{*}{50} & Control & 22.46 & 8.32 \\
\hline & & Sitrin & 27.28 & 12.69 \\
\hline & & Sitr.+Kotin. & 39.47 & 14.41 \\
\hline & & Kotingen & 29.37 & 12.36 \\
\hline & \multirow{4}{*}{75} & Control & 40.84 & 18.63 \\
\hline & & Sitrin & 48.83 & 21.49 \\
\hline & & Sitr.+Kotin. & 55.94 & 30.06 \\
\hline & & Kotingen & 49.44 & 24.16 \\
\hline \multirow{12}{*}{$\begin{array}{c}5 \text { tons } \\
\text { Compost }\end{array}$} & \multirow{4}{*}{ Zero } & Control & 19.49 & 7.90 \\
\hline & & Sitrin & 23.84 & 10.13 \\
\hline & & Sitr.+Kotin. & 30.67 & 19.02 \\
\hline & & Kotingen & 26.72 & 14.14 \\
\hline & \multirow{4}{*}{50} & Control & 32.89 & 16.75 \\
\hline & & Sitrin & 34.06 & 22.87 \\
\hline & & Sitr.+Kotin. & 45.06 & 35.00 \\
\hline & & Kotingen & 43.79 & 27.44 \\
\hline & \multirow{4}{*}{75} & Control & 43.19 & 29.03 \\
\hline & & Sitrin & 52.30 & 31.77 \\
\hline & & Sitr.+Kotin. & 60.39 & 40.29 \\
\hline & & Kotingen & 52.66 & 33.54 \\
\hline \multirow{12}{*}{$\begin{array}{l}10 \text { tons } \\
\text { Compost }\end{array}$} & \multirow{4}{*}{ Zero } & Control & 21.22 & 10.82 \\
\hline & & Sitrin & 29.68 & 11.72 \\
\hline & & Sitr.+Kotin. & 40.85 & 19.91 \\
\hline & & Kotingen & 37.32 & 16.01 \\
\hline & \multirow{4}{*}{50} & Control & 44.43 & 17.85 \\
\hline & & Sitrin & 52.64 & 22.36 \\
\hline & & Sitr.+Kotin. & 83.11 & 48.96 \\
\hline & & Kotingen & 76.33 & 35.35 \\
\hline & \multirow{4}{*}{75} & Control & 58.05 & 26.54 \\
\hline & & Sitrin & 64.53 & 34.55 \\
\hline & & Sitr.+Kotin. & 77.10 & 42.33 \\
\hline & & Kotingen & 72.94 & 41.31 \\
\hline \multicolumn{3}{|c|}{ LSD at 0.05} & 0.19 & 0.10 \\
\hline
\end{tabular}


Table 6: Means of grain\& straw yields and $\mathbf{1 0 0}$ grain weight of wheat as affected by compost, nitrogen and micronutrient compounds during both seasons of experiment.

\begin{tabular}{|c|c|c|c|c|c|c|c|}
\hline \multirow{2}{*}{\multicolumn{2}{|c|}{ Treatment }} & \multicolumn{2}{|c|}{ Grain $\left(\right.$ ard fed $\left.{ }^{-1}\right)$} & \multicolumn{2}{|c|}{ Straw ton fed ${ }^{-1}$} & \multicolumn{2}{|c|}{100 G. W. (g) } \\
\hline & & $1^{\text {st }}$ seaso & "nd season & $1^{\text {st }}$ seaso & $n 2^{\text {nd }}$ season & $1^{\text {st }}$ seas & ${ }^{\text {nd }}$ season \\
\hline \multirow{3}{*}{ A- Compost } & control & 9.84 & 10.65 & 2.38 & 2.79 & 5.01 & 4.65 \\
\hline & 5 ton & 13.29 & 11.98 & 2.88 & 3.37 & 5.42 & 4.84 \\
\hline & 10 ton & -- & 15.49 & -- & 3.62 & -- & 5.12 \\
\hline \multicolumn{2}{|l|}{ LSD } & 0.01 & 0.07 & 0.01 & 0.02 & 0.08 & 0.10 \\
\hline \multirow{3}{*}{$\begin{array}{l}\text { B-Nitrogen } \\
\text { Fert. }\end{array}$} & control & 9.36 & 8.68 & 2.14 & 2.07 & 5.08 & 4.74 \\
\hline & $50 \mathrm{~kg}$ & 11.35 & 13.37 & 2.62 & 3.04 & 5.27 & 4.87 \\
\hline & $75 \mathrm{~kg}$ & 13.98 & 16.06 & 3.13 & 4.12 & 5.29 & 5.00 \\
\hline \multicolumn{2}{|l|}{ LSD } & 0.02 & 0.03 & 0.00 & 0.01 & 0.03 & 0.06 \\
\hline \multirow{4}{*}{$\begin{array}{c}\text { C- } \\
\text { Micronutrient }\end{array}$} & Control & 10.62 & 10.55 & 2.67 & 2.64 & 4.92 & 4.71 \\
\hline & Sitrin & 11.03 & 11.87 & 2.83 & 3.04 & 5.14 & 4.81 \\
\hline & Sit.+Kot. & 12.84 & 14.83 & 2.95 & 3.89 & 5.50 & 5.06 \\
\hline & Kotingin & 11.77 & 13.57 & 2.74 & 3.45 & 5.30 & 4.89 \\
\hline \multicolumn{2}{|l|}{ LSD } & 0.16 & 0.03 & 0.01 & 0.02 & 0.03 & 0.08 \\
\hline
\end{tabular}

Table 7: Means of spike No $\mathrm{m}^{-2}$ and protein \% as affected by compost, nitrogen and micronutrient compounds during both seasons of experiment.

\begin{tabular}{|c|c|c|c|c|c|c|c|}
\hline \multirow{3}{*}{\multicolumn{2}{|c|}{ Treatment }} & \multirow{2}{*}{\multicolumn{2}{|c|}{ Spike No./m² }} & \multicolumn{4}{|c|}{ Protien\% } \\
\hline & & & & \multicolumn{2}{|c|}{ Grain } & \multicolumn{2}{|c|}{ Straw } \\
\hline & & $1^{\text {st }}$ seasc & nd season & seaso & na season & $1^{\text {st }}$ season & season \\
\hline \multirow{3}{*}{ A- Compost } & control & 168.56 & 181.80 & 11.58 & 11.24 & 3.41 & 3.72 \\
\hline & 5 ton & 186.47 & 202.02 & 12.25 & 12.36 & 3.62 & 4.67 \\
\hline & 10 ton & -- & 216.16 & -- & 13.49 & -- & 4.40 \\
\hline \multicolumn{2}{|c|}{ LSD } & 31.20 & 1.53 & 0.86 & 0.31 & 0.10 & 0.24 \\
\hline \multirow{3}{*}{ B-Nitrogen } & control & 147.00 & 166.26 & 10.36 & 10.93 & 3.04 & 3.18 \\
\hline & $50 \mathrm{~kg}$ & 173.79 & 195.62 & 11.32 & 12.57 & 3.39 & 4.92 \\
\hline & $75 \mathrm{~kg}$ & 211.75 & 238.11 & 12.55 & 13.58 & 4.10 & 5.28 \\
\hline \multicolumn{2}{|c|}{ LSD } & 23.70 & 0.76 & 0.49 & 0.63 & 0.06 & 0.15 \\
\hline \multirow{4}{*}{$\begin{array}{c}\text { C- } \\
\text { Micronutrient }\end{array}$} & Control & 161.56 & 183.80 & 11.08 & 11.86 & 3.23 & 3.67 \\
\hline & Sitrin & 176.83 & 200.08 & 11.79 & 12.35 & 3.69 & 3.98 \\
\hline & Sit.+Kot. & 187.28 & 210.01 & 12.69 & 12.75 & 3.81 & 4.84 \\
\hline & Kotingin & 184.39 & 206.09 & 12.10 & 12.49 & 3.32 & 4.58 \\
\hline \multicolumn{2}{|c|}{ LSD } & 20.08 & 20.59 & 0.31 & 0.73 & 0.03 & 0.14 \\
\hline
\end{tabular}

Data in Table 6 and 7 show slight significant increase in 100 grain weight and highest weight was recorded with 10 ton compost fed ${ }^{-1}(5.42$ and $5.12 \mathrm{~g}$ ) at 5 and 10 ton fed $^{-1}$ compost fed ${ }^{-1}$ in two seasons respectively, compared to control $(5.01$ and $4.65 \mathrm{~g})$. These results are identical with those in spike No $\mathrm{m}^{-2}$ where the top value was 216.16 spikes in $\mathrm{m}^{2}$ compared with control (181 spikes in $\mathrm{m}^{2}$ ) in $2^{\text {nd }}$ season, as in $1^{\text {st }}$ season.

Also, the crud protein percentage in Table 7 showed that the significant increase due to compost application and the 10 ton compost fed ${ }^{-1}$ treatment recorded the highest mean value $(13.49 \%)$ in $1^{\text {st }}$ season followed by 5 ton fed $^{-1}$ compared to control 11.58 and $11.24 \%$ in both seasons, respectively. 
Also, in straw the 5 ton fed ${ }^{-1}$ treatment recorded top value $(4.67 \%)$ followed by 10 ton fed ${ }^{-1}(4.4 \%)$ compared to control (3.72\%). The results trend similar with Sarwar, (2005); Sarwar et al., (2007); and Srwar, et al (2008).

\section{B. Nitrogen Effect:}

Highlsignificant increases in grain and straw yield of wheat were observed in Table 6 due to nitrogen fertilization. The $75 \mathrm{~kg} \mathrm{~N}^{-1}$ mean treatment recorded the highest value where it was 13.98 and 16.06 ard fed $^{-1}$ in both seasons followed by $50 \mathrm{~kg} \mathrm{~N}^{-1} \mathrm{fed}^{-1}$ compared to control (9.36 and 8.68 ard fed $\left.^{-1}\right)$. Also, the heighest mean values in the straw yield were with $75 \mathrm{~kg}$ $\mathrm{N} \mathrm{fed}{ }^{-1}$ (3.13 and 4.12 ton fed $\left.{ }^{-1}\right)$ compared to control $\left(2.14\right.$ and 2.07 ton fed $\left.^{-1}\right)$. slight significant increase in 100 grain weight was obtained, while all nitrogen treatments excelled than control.

Data in Table 7 show significant increase in means of spike No $\mathrm{m}^{-2}$ with $75 \mathrm{~kg} \mathrm{~N} \mathrm{fed}^{-1}$ and the highest values were 211.75 and 238.11 spike $\mathrm{m}^{-2}$ compared to control (147 and 166) in both seasons, respectively.

The crud protein \% show significant increase in grain and straw yield due to nitrogen application and this because the importance of nitrogen in improving yield characters and quality, the highest increases significant in grain protein were with $75 \mathrm{~kg} \mathrm{~N}^{-1} \mathrm{fed}^{-1}(12.55$ and $13.58 \%)$ and the less means were with control (10.36 and $10.93 \%)$. Also, in straw. This trend could enhance with Abdelmottalib, (2003) and El-Zeky, (2005).

\section{Micronutrient compounds effect:}

Significant increases in grain and straw yields were obtained in Tables 6 and 7 due to micronutrient compounds application and all micronutrient compounds treatments excelled control. Therefore, these results indicate that the role of micronutrients addition in grain and straw improving of wheat. The grain yield increases with all micronutrient compounds than control and the highest mean was with sitrin + kotingin treatment followed by solo kotingin then sitrin and the values were 12.84 and $14.83 \mathrm{ard} \mathrm{fed}^{-1}$ with sitrin + kotingin compared to control (10.62 and $10.55 \mathrm{ard} \mathrm{fed}^{-1}$ ). This trend is identical with straw yield, 100 grain weight, spike No $\mathrm{m}^{2}$ and protein $\%$ in grain and straw. Similar results were reported by Malakouti and Tehrani, (2005).

D. Interaction effect among compost, nitrogen and micronutrient compounds on wheat yield and yield components.

As obvious in Tables 8 and 9, the grain and straw yield mean values increased with compost, nitrogen and micronutrient compounds fertilization interaction and increased from zero up to 10 ton fed $^{-1}$ compost and nitrogen fertilization from zero to 50 to $75 \mathrm{~kg} \mathrm{~N}$ fed $^{-1}$, where the highest values were 17.92 with sitrin + kotingin at $75 \mathrm{~kg} \mathrm{~N}$ fed $^{-1}$ followed by kotigin then sitrin compared to conyrol $\left(6.32\right.$ ard fed $\left.^{-1}\right)$ in $1^{\text {st }}$ season, also in $2^{\text {nd }}$ season the data showed the highest value, it was $22.07 \mathrm{ard} \mathrm{fed}^{-1}$ with sitrin + kotingin at $50 \mathrm{~kg}$ $\mathrm{N}$ fed ${ }^{-1}$ with 10 ton compost fed ${ }^{-1}$ followed by solo Kotngen treatmen (20.77 ard $\mathrm{fed}^{-1}$ ) then sitrin + kotigin treatment at $75 \mathrm{~kg} \mathrm{~N}$ fed $^{-1}$ with 10 ton fed 
compost (20.10 ard fed $\left.^{-1}\right)$ compared to control $\left(6.38 \mathrm{ard} \mathrm{fed}^{-1}\right)$. This increases in grain yield values are due to combination of compost and micronutrient compounds application along with nitrogen fertilization. These results go with those reported by Malakouti, (2000); Malakouti and Tehrani, (2005); Malakouti, (2007); Rehm and Albert, (2006).

Also, the straw yield data as shown in Tables 8 and 9 revealed that the straw yield values go in the same trend of grain yield results, where the sitrin + kotingin treatment is top value which increased with all compost and nitrogen levels followed by kotingin then sitrin where, the highest value in $2^{\text {nd }}$ season was $\left(5.56\right.$ ton $\left.\mathrm{fed}^{-1}\right)$ with Citrine + kotingin with $50 \mathrm{~kg} \mathrm{~N}^{-1}$ at 10 ton fed ${ }^{-1}$ compost followed by kotingin at $50 \mathrm{~kg} \mathrm{~N}$ fed $^{-1}\left(4.89 \mathrm{ton} \mathrm{fed}^{-1}\right)$ at 10 ton fed ${ }^{-1}$ compost then sitrin + kotingin at $75 \mathrm{~kg} \mathrm{~N}$. fed ${ }^{-1}\left(4.86\right.$ ton fed $\left.{ }^{-1}\right)$ at 10 tons compost fed $^{-1}$. These results indicate that the combination between micronutrients fertilization and compost application maximizes the nitrogen fertilization therefore, $50 \mathrm{~kg} \mathrm{~N}_{\text {fed }}{ }^{-1}$ with 10 ton compost fed ${ }^{-1}$ excelled $75 \mathrm{~kg}$ $\mathrm{N}$ fed ${ }^{-1}$ treatment and $50 \mathrm{~kg} \mathrm{~N} \mathrm{fed}^{-1}$ with compost and micronutrient equal or excelled $75 \mathrm{~kg} \mathrm{~N}^{-1}{ }^{-1}$ without compost and micronutrient. This is identical with Sarwar et al. (2007) and Sarwar et al. (2008).

Table 8: Effect of the interaction between compost, nitrogen and micronutrient compounds on yield and yield component of wheat during the 1st season

\begin{tabular}{|c|c|c|c|c|c|c|c|c|}
\hline \multicolumn{3}{|c|}{ Treatment } & \multirow{2}{*}{$\begin{array}{l}\text { Grain } \\
\text { ard } \\
\text { Fed }^{-1}\end{array}$} & \multirow[b]{2}{*}{$\begin{array}{l}\text { Straw ton } \\
\text { fed }^{-1}\end{array}$} & \multirow[b]{2}{*}{$\begin{array}{l}\text { spikes } \\
\text { No } m^{-2}\end{array}$} & \multirow{2}{*}{$\begin{array}{c}100 \\
\text { Grain } \\
\text { W. (g) }\end{array}$} & \multicolumn{2}{|c|}{ Protein \% } \\
\hline $\begin{array}{l}\text { Compost } \\
\text { ton fed }^{-1}\end{array}$ & $\begin{array}{c}\text { Nitrogen } \\
\mathrm{Kg} \mathrm{fed}^{-1}\end{array}$ & $\begin{array}{l}\text { Micronutrient } \\
\text { Compounds }\end{array}$ & & & & & Grain & Straw \\
\hline \multirow{12}{*}{$\begin{array}{l}\text { Without } \\
\text { Compost }\end{array}$} & \multirow{4}{*}{0} & Control & 6.32 & 1.81 & 4.64 & 133.0 & 9.20 & 2.25 \\
\hline & & Sitrin & 7.11 & 1.87 & 4.83 & 147.0 & 10.04 & 3.19 \\
\hline & & Sitr.+Kotin. & 8.29 & 1.84 & 5.20 & 154.0 & 10.91 & 3.63 \\
\hline & & Kotingen & 7.21 & 1.83 & 5.15 & 146.0 & 10.48 & 2.63 \\
\hline & \multirow{4}{*}{50} & Control & 9.46 & 2.23 & 4.91 & 157.7 & 10.95 & 3.19 \\
\hline & & Sitrin & 9.63 & 2.31 & 5.02 & 173.0 & 11.65 & 3.75 \\
\hline & & Sitr.+Kotin. & 11.61 & 2.43 & 5.25 & 167.3 & 12.35 & 3.00 \\
\hline & & Kotingen & 10.57 & 2.23 & 4.99 & 180.0 & 11.60 & 2.81 \\
\hline & \multirow{4}{*}{75} & Control & 11.11 & 2.81 & 4.60 & 156.0 & 11.88 & 3.75 \\
\hline & & Sitrin & 11.68 & 3.05 & 5.10 & 177.3 & 12.82 & 3.94 \\
\hline & & Sitr.+Kotin. & 13.37 & 3.09 & 5.38 & 219.7 & 13.98 & 4.69 \\
\hline & & Kotingen & 11.75 & 3.03 & 5.06 & 211.7 & 13.10 & 4.13 \\
\hline \multirow{12}{*}{$\begin{array}{l}5 \text { tons } \\
\text { Compost }\end{array}$} & \multirow{4}{*}{0} & Control & 10.95 & 2.33 & 4.95 & 138.3 & 10.17 & 3.00 \\
\hline & & Sitrin & 10.98 & 2.48 & 5.07 & 154.3 & 10.59 & 3.42 \\
\hline & & Sitr.+Kotin. & 12.53 & 2.56 & 5.62 & 155.3 & 11.29 & 3.56 \\
\hline & & Kotingen & 11.51 & 2.37 & 5.22 & 148.0 & 10.94 & 3.00 \\
\hline & \multirow{4}{*}{50} & Control & 11.49 & 2.78 & 5.12 & 169.3 & 11.87 & 3.25 \\
\hline & & Sitrin & 12.01 & 2.94 & 5.35 & 175.7 & 12.22 & 3.75 \\
\hline & & Sitr.+Kotin. & 13.32 & 3.23 & 5.81 & 184.7 & 13.02 & 3.69 \\
\hline & & Kotingen & 12.72 & 2.83 & 5.70 & 182.7 & 12.52 & 3.54 \\
\hline & \multirow{4}{*}{75} & Control & 14.40 & 3.01 & 5.32 & 215.0 & 12.39 & 3.94 \\
\hline & & Sitrin & 14.80 & 3.41 & 5.45 & 233.7 & 13.43 & 4.13 \\
\hline & & Sitr.+Kotin. & 17.92 & 3.50 & 5.71 & 242.7 & 14.59 & 4.31 \\
\hline & & Kotingen & 16.84 & 3.15 & 5.69 & 238.0 & 13.98 & 3.83 \\
\hline \multicolumn{3}{|c|}{ LSD } & 0.47 & 0.07 & 0.14 & 5.5 & 0.06 & 0.05 \\
\hline
\end{tabular}


Data in Tables 8 and 9 show that the spike $\mathrm{No}^{-2}$ values increase with compost from zero up to 10 ton compost fed ${ }^{-1}$ and from zero up to $75 \mathrm{~kg}$ $\mathrm{N}$ fed ${ }^{-1}$ for $\mathrm{N}$-fertilization. The top value was 275.2 spike with sitrin + kotingin treatment with 10 ton fed ${ }^{-1}$ compost followed by kotingin 169.9 spike with 10 ton compost fed ${ }^{-1}$.

Table 9: Effect of the interaction between compost, nitrogen and micronutrient compounds on yield and yield components of wheat in the second season.

\begin{tabular}{|c|c|c|c|c|c|c|c|c|}
\hline \multicolumn{3}{|c|}{ Treatment } & \multirow[b]{2}{*}{$\begin{array}{c}\text { Grain } \\
\text { ard fed }^{-1}\end{array}$} & \multirow[b]{2}{*}{$\begin{array}{l}\text { Straw ton } \\
\text { fed }^{-1}\end{array}$} & \multirow[b]{2}{*}{$\begin{array}{l}\text { spikes } \\
\text { No } \mathrm{m}^{-2}\end{array}$} & \multirow{2}{*}{$\begin{array}{c}100 \\
\text { Grain } \\
\text { W. (g) }\end{array}$} & \multicolumn{2}{|c|}{ Protein \% } \\
\hline $\begin{array}{l}\text { Compost } \\
\text { ton }^{-1 e d}\end{array}$ & $\begin{array}{l}\text { Nitrogen } \\
\text { kg fed }^{-1}\end{array}$ & $\begin{array}{l}\text { Micronutrient } \\
\text { Compounds }\end{array}$ & & & & & Grain & Straw \\
\hline \multirow{12}{*}{$\begin{array}{l}\text { Without } \\
\text { Compost }\end{array}$} & \multirow{4}{*}{ Zero } & Control & 6.38 & 1.40 & 146.3 & 4.45 & 9.21 & 2.40 \\
\hline & & Sitrin & 6.66 & 1.83 & 161.7 & 4.52 & 9.68 & 2.69 \\
\hline & & Sitr.+Kotin. & 7.28 & 1.94 & 169.4 & 4.60 & 9.97 & 2.96 \\
\hline & & Kotingen & 6.81 & 1.83 & 160.6 & 4.58 & 9.72 & 2.89 \\
\hline & \multirow{4}{*}{50} & Control & 7.97 & 1.99 & 168.7 & 4.49 & 10.99 & 3.39 \\
\hline & & Sitrin & 9.51 & 2.84 & 185.1 & 4.57 & 11.18 & 3.63 \\
\hline & & Sitr.+Kotin. & 13.05 & 3.11 & 179.0 & 4.87 & 11.79 & 3.76 \\
\hline & & Kotingen & 10.15 & 2.83 & 192.6 & 4.62 & 11.28 & 3.55 \\
\hline & \multirow{4}{*}{75} & Control & 13.18 & 3.61 & 166.9 & 4.52 & 11.72 & 4.19 \\
\hline & & Sitrin & 14.72 & 3.75 & 189.7 & 4.72 & 12.93 & 4.66 \\
\hline & & Sitr.+Kotin. & 17.14 & 4.41 & 235.0 & 5.02 & 13.41 & 5.54 \\
\hline & & Kotingen & 14.87 & 3.92 & 226.5 & 4.85 & 12.96 & 5.01 \\
\hline \multirow{12}{*}{5 tons } & \multirow{4}{*}{ Zero } & Control & 6.99 & 1.73 & 152.2 & 4.57 & 10.88 & 2.67 \\
\hline & & Sitrin & 8.23 & 2.17 & 169.8 & 4.66 & 11.30 & 2.73 \\
\hline & & Sitr.+Kotin. & 10.19 & 3.22 & 170.9 & 4.76 & 11.74 & 4.66 \\
\hline & & Kotingen & 9.11 & 2.47 & 162.8 & 4.71 & 11.44 & 3.35 \\
\hline & \multirow{4}{*}{50} & Control & 10.61 & 2.58 & 186.3 & 4.72 & 12.09 & 4.37 \\
\hline & & Sitrin & 10.80 & 3.22 & 193.2 & 4.80 & 12.30 & 4.45 \\
\hline & & Sitr.+Kotin. & 14.01 & 4.15 & 203.1 & 5.12 & 12.55 & 4.93 \\
\hline & & Kotingen & 13.76 & 3.61 & 200.9 & 4.85 & 12.41 & 6.22 \\
\hline & \multirow{4}{*}{75} & Control & 13.59 & 4.08 & 227.9 & 4.81 & 12.78 & 4.93 \\
\hline & & Sitrin & 15.09 & 4.12 & 247.7 & 4.89 & 13.52 & 5.01 \\
\hline & & Sitr.+Kotin. & 16.27 & 4.92 & 257.2 & 5.21 & 13.74 & 6.38 \\
\hline & & Kotingen & 15.16 & 4.19 & 252.3 & 4.94 & 13.55 & 6.36 \\
\hline \multirow{12}{*}{10 tons } & \multirow{4}{*}{ Zero } & Control & 7.10 & 2.02 & 162.8 & 4.89 & 11.65 & 2.81 \\
\hline & & Sitrin & 9.80 & 2.06 & 181.7 & 4.97 & 11.81 & 3.06 \\
\hline & & Sitr.+Kotin. & 13.34 & 3.02 & 182.8 & 5.06 & 11.95 & 3.45 \\
\hline & & Kotingen & 12.26 & 2.51 & 174.2 & 5.04 & 11.87 & 3.39 \\
\hline & \multirow{4}{*}{50} & Control & 12.86 & 2.91 & 199.3 & 4.94 & 13.48 & 3.59 \\
\hline & & Sitrin & 14.92 & 3.21 & 206.8 & 5.02 & 13.76 & 4.08 \\
\hline & & Sitr.+Kotin. & 22.07 & 5.56 & 217.4 & 5.36 & 14.68 & 5.15 \\
\hline & & Kotingen & 20.77 & 4.89 & 215.0 & 5.08 & 14.33 & 4.23 \\
\hline & \multirow{4}{*}{75} & Control & 16.25 & 3.45 & 243.9 & 4.97 & 13.93 & 4.68 \\
\hline & & Sitrin & 17.14 & 4.21 & 265.0 & 5.19 & 14.68 & 5.54 \\
\hline & & Sitr.+Kotin. & 20.10 & 4.76 & 275.2 & 5.53 & 14.96 & 6.69 \\
\hline & & Kotingen & 19.21 & 4.86 & 269.9 & 5.34 & 14.81 & 6.18 \\
\hline \multicolumn{3}{|c|}{ LSD } & 1.49 & 0.07 & 2.3 & 0.07 & 0.06 & 0.05 \\
\hline
\end{tabular}




\section{El-Hamdi, Kh. H. et al.}

Also, data in same Tables show that the 100 grain weight values increase slightly significant as affected by compost and micronutrient compounds application, the highest value was $5.81 \mathrm{~g}$ in $1^{\text {st }}$ season with $50 \mathrm{~kg}$ $\mathrm{N}$ fed ${ }^{-1}$ with 10 ton compost and in $2^{\text {nd }}$ season the highest was $5.52 \mathrm{~g}$ with 10 ton compost fed ${ }^{-1}$ with $75 \mathrm{~kg} \mathrm{~N} \mathrm{fed}^{-1}$ followed by sitrin + kotingin at $50 \mathrm{~kg} \mathrm{~N}$ fed-1 compared to control ( 4.64 and $4.45 \mathrm{~g}$ ). in both season, respectively.

Data in Tables 8 and 9 show that the crude protein percent increases with the addition of compost and nitrogen fertilization and obtained that the sitrin + Kotngen or both of them alone led to significant increases in protein \% and the highest value was with $75 \mathrm{~kg} \mathrm{~N}$. fed $\mathrm{f}^{-1}$ at $10 \mathrm{ton} \mathrm{fed}^{-1}$ of compost $(14.59 \%)$ in $1^{\text {st }}$ season with $50 \mathrm{~kg} \mathrm{~N}$ fed-1 and in $2^{\text {nd }}$ season the highest was $14.96 \%$ and the less value was $9.2 \%$ with control. Also the protein percent data in straw, the top value was $6.69 \%$ with sitrin + kotingin treatment at 10 ton compost with $75 \mathrm{~kg} \mathrm{~N}$ fed ${ }^{-1}$ followed by kotingin and the less protein \% was $2.4 \%$ with control, this trend as reported with Cheuk et al. (2003); Sarwar et al. (2007); Sarwar et al. (2008); (Malakouti, (2000); Malakouti and Tehrani (2005); Malakouti, (2007); Rehm and Albert (2006)

\section{REFERENCES}

Abdel- Mottalb, El. M. (2003): Studies on the fertilizer requirements of wheat crop under Fayoum Governorate condition. M. Sc. Thesis, Fac. of Agric., Fayoum, Cairo Univ.

Asghar HN, M. Ishaq, Z. A. Zahir, M. Khalid, M. Arshad,(2006) Response of radish to integrated use of nitrogen fertilizer and recycled organic waste. Pak J Bot 38: 691-700.

Baker, D. 1979. Report on cereal foods. Journal Association of Official Analytical

Chemists 62: 369-370.

Black, C. A. (1965). "Methods of Soil Analysis." Part 1 and 2 USA, Madison, Wiscansin

Cheuk W, K. V. Lo, R. M. R. Branion, B. Fraser, (2003). Benefits of sustainable waste management in the vegetable greenhouse industry. J Environ Sci Health 38: 855-863.

Delin, S., A. Nyberg, B. Lindén,, M. Ferm,, G. Torstensson, C. Lerenius, I. Gruvaeus, (2008). Impact of crop protection on nitrogen utilisation and losses in winter wheat production. Eur. J. Agron. 28, 361-370.

El-Zeky, M. M. (2005): Response of wheat to biofertilizer inoculation under different levels of inorganic nitrogen. J. Agric. Sci. Mansoura Univ., 30 (1): 701-710.

Gomez, K. A. and A. A. Gomez (1984)." Statistical Procedures for Agricultural Research". John Wiley and Sons. Inc. New York.

Jackson, M. L. (1967). "Soil Chemical Analysis." Printic Hall of India New Delhi. 
Kirda, C., Derici, M.R., Schepers, J.S., 2001. Yield response and N-fertiliser recovery of rainfed wheat growing in the Mediterranean region. Field Crop Res. 71, 113-122

Lindsay, W.L. and W.A Norvell. (1978). Development of DTPA soil test for Zn, iron, manganese and copper. Soil Science Society of America Journal, 42: $42-428$.

Malakouti, M.J. (2000). Balanced nutrition of wheat: An approach towards self-sufficiency and enhancement of national health. "A compilation of papers". Ministry of Agriculture, Karaj, Iran. 544 pp.

Malakouti, M.J. and M.M. Tehrani, (2005). Effects of micronutrient on the yield and quality of agricultural products: Micronutrient with macroeffects. Tarbiat Modares University Press. Tehran, Iran. p. 445.

Malakouti M.J. (2007). Zinc is a neglected element in the life cycle of plants: A review. Middle East. Rus. J. Plant Sci. and Biotech. 1: 1- 12.

Olsen, S. R.; C. V. Cole; F. S. Watanab and L. A. Dean (1954). Stimulation of available phosphorus in soil by extraction with sodium bicarbonate. U. S. Dept. Agric. Cric. No. 939.

Piper C.S. (1950). "Soil and Plant Analysis", Inter. Science, Publisher. Inc. Newyork.

Pregle, F. (1945)." Qantitative Organic Micro analyses". $4^{\text {th }}$ Edit, J. X. Churchill L. td. London.

U. S. Salinity Laboratory Staff (1954). "Diagnosis and improvement of saline and alkali soils". USDA. Agric. Handbook No.60, Washington,

Rehm G, and S. Albert, (2006). Micronutrients and Production of Hard Red Spring Wheat. Minnesota Crop News. March 7, 2006, p: 1-3.

Sarwar, G (2005). Use of compost for crop production in Pakistan. Ökologie und Umweltsicherung26/2005. Universität Kassel, Fachgebiet Landschaftsökologie and Naturschutz, Witzenhausen, Germany. Chemists 62: 369-370.

Sarwar G, N. Hussain, H. Schmeisky, S. Muhammad, (2007) Use of compost an environment friendly technology for enhancing rice-wheat production in Pakistan. Pak J Bot 39 (5): 1553-1558.

Sarwar G, N. Hussain, H. Schmeisky, S. Muhammad, M. Ibrahim, E. Safdar (2008) Improvement of soil physical and chemical properties with compost application in rice-wheat cropping system. Pak J Bot 40: 275282.

Stevens, W.B., R. G. Hoeft,, R.L. Mulvaney, (2005). Fate of nitrogen-15 in a long-term nitrogen rate study: II. Nitrogen uptake efficiency. Agron. J. 97, 1046-1053.

Wang, GH., D. Achim,, W. Christian,, Q. Z. Sun,, R.X. Fu, (2001). Performance of sitespecific nutrient management for irrigated rice in southeast China. Agron. J. 93, 869-878. 


\section{El-Hamdi, Kh. H. et al.}

تأثيرالتسميا بالكمبوست ومركبات العناصر الصغرى مـع التسميد النيتروجينى على محصول القمح ومكوناته.

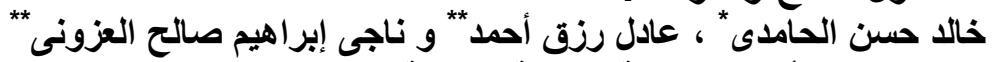

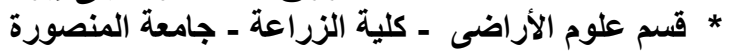

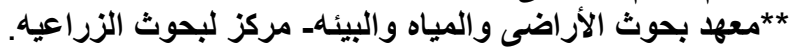

التسميد النيتروجينى هو مفتاح الحصول على زيادة المحصول ولكن باستخدام كميات كبيره منه تقل النقل

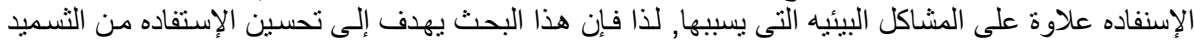

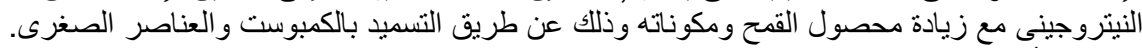

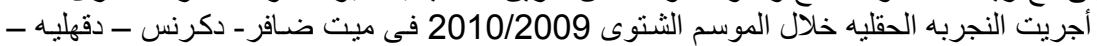

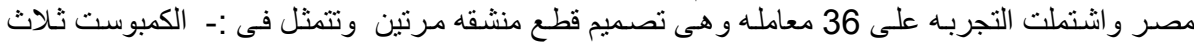

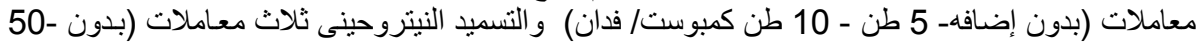

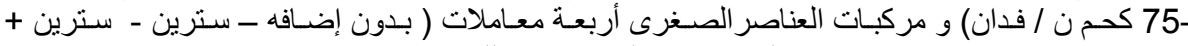

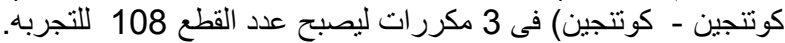
ويمكن تلخيص النتائج في :-

1- التسميد النيتروجينى يزيد معنويا النيتروجين الممتص و و محصول الحبوب و التبن و عدد السنابل / م2 إ2

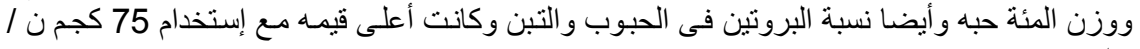

2- أظهرت النتائج زياده معنويه في النيتروجين الممتص ومحصول الحبوب و التبن وكنلك عدد السنابل ووزن المائة حبه وأيضا نسبة البروتين نتيجة إستخدام الكمبوست وكانت أعلى معامله مع إستخدم 10

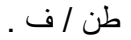

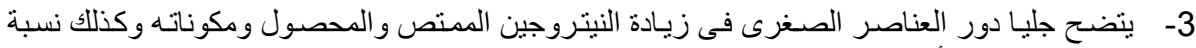

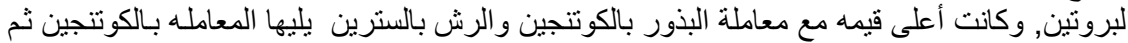

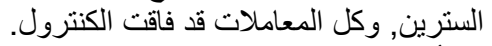

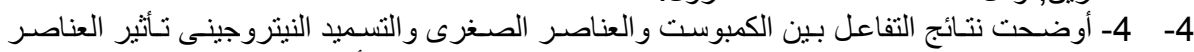

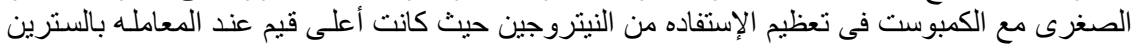

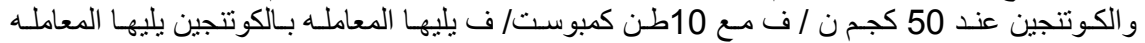
بالسترين + الكوتنجين عند 75 كجم ن / ف مع 10 طن كمبوست

الإسنتتاج :-

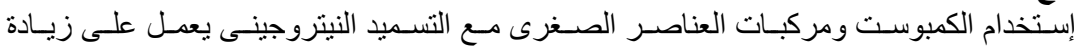

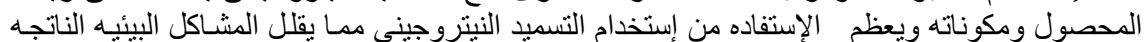
عن كثرة إنتخدامه ويحسن كمية وجودة المحصول.

كلية الزراعة - جامعة المنصورة مركز البحوث الزراعية

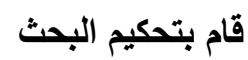

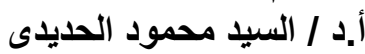
أ.د / جمال الدين عبد الخالق بدور الدال 